\title{
ELECTROCHEMICAL DETERMINATION OF THE STANDARD GIBBS FREE ENERGY CHANGE OF THE GRAPHITE-OXYGEN REACTIONS
}

\author{
S. K. DAS and E. E. HUCKE \\ Department of Materials and Metallurgical Engineering, The University of Michigan, Ann Arbor, MI 48104, U.S.A.
}

(Received 21 June 1974)

Abstract-A calcia doped zirconia solid oxide electrolyte galvanic cell was investigated in the temperature range of $700-950^{\circ} \mathrm{C}$ to directly and more accurately measure the standard Gibbs free energy change of the following reactions:

$$
\begin{gathered}
\mathrm{CO}(\mathrm{g})+1 / 2 \mathrm{O}_{2}(\mathrm{~g})=\mathrm{CO}_{2}(\mathrm{~g}) \\
\mathrm{C}_{\text {(zraphite) }}+\mathrm{CO}_{2}(\mathrm{~g})=2 \mathrm{CO}(\mathrm{g}) .
\end{gathered}
$$

The results obtained in the present investigation are well within the scatter band of the calorimetric and spectroscopic data.

The best available data on the standard Gibbs free energy change of the reactions:

$$
\begin{aligned}
& \mathrm{CO}(\mathrm{g})+1 / 2 \mathrm{O}_{2}(\mathrm{~g})=\mathrm{CO}_{2}(\mathrm{~g}) \\
& \mathrm{C}_{\text {(graphite) }}+\mathrm{CO}_{2}(\mathrm{~g})=2 \mathrm{CO}(\mathrm{g})
\end{aligned}
$$

have been indirectly computed using calorimetric and spectroscopic data[1]. The directly measured data by gas equilibrium methods are either less accurate than the indirectly calculated values or have only historical importance. In view of the great importance of the reactions R-I and R-II in the problems of process metallurgy and fossil fuels energy conversion, it was thought worthwhile to determine the equilibrium constants of these reactions by a directly measured and potentially accurate method, the need for which has already been emphasized by Wagner[2] in one of his recent review papers.

\section{EXPERIMENTAL TECHNIQUE AND PROCEDURE}

A solid oxide electrolyte $\left(\mathrm{ZrO}_{2}-15\right.$ mole $\left.\% \mathrm{CaO}\right)$ cell was employed to measure the oxygen partial pressure in equilibrium with $\mathrm{CO}-\mathrm{CO}_{2}$ gas mixture and graphite. The calcia doped zirconia solid electrolyte is known to satisfy the necessary experimental conditions of conductivity and stability in the temperature and oxygen partial pressure range of interest in this work [3].

The cell C-I was investigated to measure the standard Gibbs free energy change of the reaction R-I

$$
\text { Pt/Air(g) } / / \text { Solid Electrolyte } / / \mathrm{CO}(\mathrm{g}), \mathrm{CO}_{2}(\mathrm{~g}) / \mathrm{Pt}
$$

Temperature range: $700-950^{\circ} \mathrm{C}$

Oxygen partial pressure range:

Cell atmosphere (Right hand):

$$
10^{-21}\left(700^{\circ} \mathrm{C}\right)-10^{-13}\left(950^{\circ} \mathrm{C}\right) \mathrm{atm}
$$

Known ratio of $\mathrm{CO} / \mathrm{CO}_{2}$ gas mixture.
The e.m.f. $E$ of the cell C-I as a function of temperature gives the standard Gibbs free energy change $\Delta G_{\mathrm{I}}^{\circ}$ (and hence the enthalpy and entropy changes) of the reaction R-I.

$$
\Delta G_{\mathrm{I}}^{\circ}=\left[R T \ln \frac{\left[p_{\mathrm{O}_{2}}^{\mathrm{I}}\right]^{1 / 2}}{\left[p_{\mathrm{CO}_{2}} / p_{\mathrm{Co}}\right]^{\mathrm{n}}}\right]-2 E F
$$

where $p_{\mathrm{O}_{2}}^{\mathrm{I}}$ and $\left[p_{\mathrm{Co}} / p_{\mathrm{Co}}\right]^{\mathrm{II}}$ are the oxygen partial pressure of left hand electrode (i.e. air) and carbon dioxidemonoxide ratio of the right hand electrode respectively, and the other symbols have their usual meaning.

The cell C-II was investigated to directly and accurately measure the $\Delta G_{\text {II }}^{\circ}$ or the equilibrium constant $K_{\text {II }}$ of the Boudouard reaction R-II.

$\mathrm{Pt} /$ Air(g)//Solid Electrolyte//Graphite, $\mathrm{CO}(\mathrm{g}), \mathrm{CO}_{2}(\mathrm{~g}) / \mathrm{Pt}$

Temperature range: $\quad 850-950^{\circ} \mathrm{C}$

Oxygen partial pressure range:

$10^{-20}\left(850^{\circ} \mathrm{C}\right)-10^{-19}\left(950^{\circ} \mathrm{C}\right)$ atm

Cell atmosphere (Right hand):

$\mathrm{CO}-\mathrm{CO}_{2}$ gas mixture in equilibrium with graphite

The equilibrium constant $K_{\mathrm{n}}$ can be directly related to the total system pressure, $P$, oxygen partial pressure $p_{O_{2}}^{l}$ of the left hand electrode (i.e. air), standard Gibbs free energy change $\Delta G_{\mathrm{I}}^{\circ}$ of reaction R-I, and the experimentally measured values of e.m.f. $E$ of the cell C-II as:

$$
K_{\mathrm{II}}=4 P\left\{\left[1+2\left(p_{O_{2}}^{\mathrm{I}}\right)^{1 / 2} \mathrm{e}^{-\left(2 E F+\Delta \sigma_{2} / R T\right.}\right]^{2}-1\right\}^{-1} .
$$

The solid electrolyte cell arrangement, and other experimental details have been described in considerable detail elsewhere[1]. An electrolyte tube (1/2 in. o.d. $x$ $3 / 8$ in. i.d. $\times 24$ in. long) was used to hest fulfill the requirements of the complete electrode isolation. The graphite electrode pellets were obtained from the Union 
Carbide AGSR grade. The AGSR is extruded, fine grained graphite made of calcined petroleum coke and has an average ash content of $0.12 \%$ and a xylene immersion density of $2.22 \mathrm{~g} / \mathrm{cm}^{3}$.

Carbon monoxide was purified of oxygen, carbon dioxide and moisture by passing it through a series of columns containing BTS catalyst in the reduced form, ascarite, and $\mathrm{P}_{2} \mathrm{O}_{5}$, respectively. Carbon dioxide was purified by passing it through the columns of dehydrating compounds and BTS catalyst in both oxidized and reduced forms. Purified $\mathrm{CO}$ and $\mathrm{CO}_{2}$ gases were mixed for a controlled oxygen potential by using constant pressure head capillary flow meters. The flow rate was measured by monitoring the rise of a soap bubble in a graduated tube of uniform cross-section, e.g. a soap bubble flow meter. A needle valve was also used in conjunction with gas regulator to further ensure the uniformity of the gas flow rate.

The starting of each run consisted of assembling the cell, connecting it to the gas purification and mixing system, evacuating the cell, filling the cell chambers with desired gas $\left(\mathrm{CO}_{2}\right.$ for cell $\mathrm{C}$-II $)$ or gas mixture $\left(\mathrm{CO}_{2}-\mathrm{CO}\right.$ gas mixture for cell $\mathrm{C}$-I) and finally starting the heating cycle. The criteria adopted for equilibrium was that the cell potential variation be random. The cell was evacuated at each temperature and then filled with $\mathrm{CO}_{2}$ gas or $\mathrm{CO}_{2}-\mathrm{CO}$ gas mixture. This was done to avoid any deposition of carbon during cooling.

\section{RESULTS AND DISCUSSION}

In order to check the functioning of the solid electrolyte cell, several experiments were run with $\mathrm{Pt}$ on both sides of the electrolyte and then with identical graphite on both sides in order to verify that no stray e.m.f. was involved. The cell voltages measured were always less than $0.1 \mathrm{mV}$ in the entire temperature range of $600-1150^{\circ} \mathrm{C}$.

A rather extensive set of check runs (in the pertinent temperature and oxygen partial pressure range) was made to insure precision and otherwise check experimental procedures. This series of runs was carried out on oxides (NiO, $\mathrm{CoO}$ and "FeO") with known thermodynamic properties in order to verify cell configurations, electrical and temperature measurement techniques, gas train functioning, thermal diffusion effects and solid electrolyte composition. In all cases, extremely gratifying confirmations were found.

A controlled ratio of $\mathrm{CO}_{2}$ and $\mathrm{CO}$ was prepared at room temperature by mixing the individually purified gases at flow rates of 0.33 and $0.12 \mathrm{~cm}^{3} / \mathrm{sec}$, respectively, fixing a $p_{\mathrm{co}} / p_{\mathrm{CO}}$ ratio of 2.75 . The measured electromotive force of the cell $\mathrm{C}-\mathrm{I}$ in the temperature range of $700-950^{\circ} \mathrm{C}$ gives the oxygen partial pressure of $\mathrm{CO}_{2} / \mathrm{CO}$ mixture, which subsequently yields the standard Gibbs free energy change, $\Delta G_{1}^{\circ}$ of reaction $\mathrm{R}-\mathrm{I}$.

The oxygen partial pressure of $\mathrm{CO}_{2} / \mathrm{CO}$ mixture in equilibrium with graphite was determined from the e.m.f. output of cell $\mathrm{C}-1 \mathrm{II}$. Using the previously determined value of the equilibrium constant $K_{1}$ of the reaction R-I, the $p_{\mathrm{CO}_{2}} / p_{\mathrm{Co}}$ ratio in equilibrium with graphite, and hence the equilibrium constant $K_{\mathrm{II}}$ was calculated. The results of the present investigation along with the scatter band of \pm 600 and \pm 1100 cal $/ \mathrm{g}$-mole in the calorimetric data [4] for the standard free energy change of reactions R-I and R-II respectively, are shown in Figs. 1 and 2. Table 1 lists the

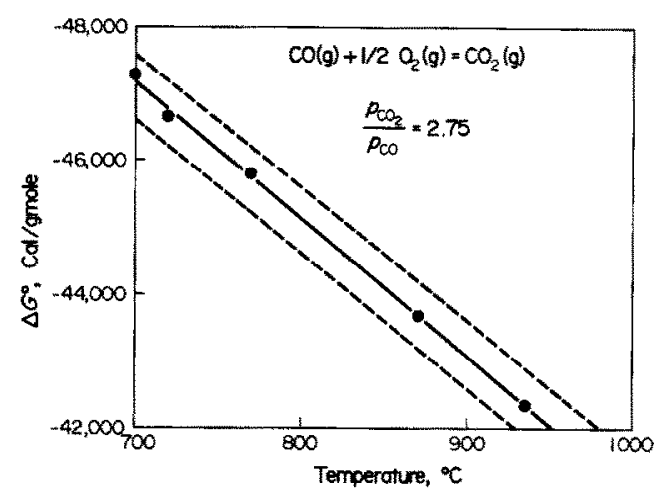

Fig. 1. Free energy-temperature relationship for $\mathrm{CO}-\mathrm{O}_{2}-\mathrm{CO}_{2}$ equilibrium. - Present study; --.--, scatter in calorimetric data [4].

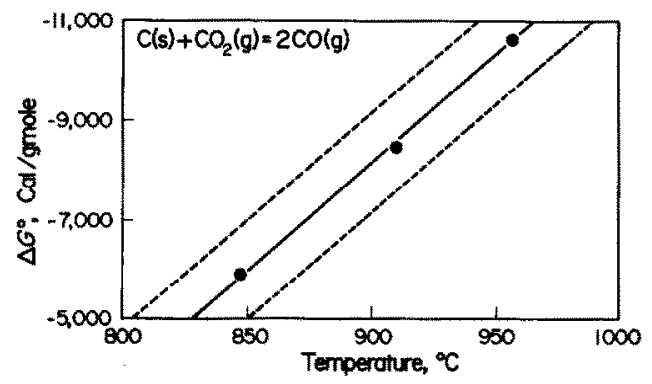

Fig. 2. Free energy-temperature relationship for $\mathrm{C}-\mathrm{CO}_{-} \mathrm{CO}_{2}$ equilibrium. O, Present study; ----, scatter band in calorimetric data[4].

$\Delta G^{\circ}$ values of all the four reactions involving graphite and carbon oxides obtained in the present study and the best available data in the literature indirectly calculated from calorimetric and spectroscopic results. The values of estimated uncertainty are also listed. The $\Delta G^{\circ}$ values of reactions R-I and R-II were directly measured from experimental data, whereas that of reactions $R-I I I$ and R-IV have been indirectly calculated from $\Delta G_{\mathrm{I}}^{\circ}$ and $\Delta G_{\mathrm{II}}^{\circ}$.

$$
\begin{array}{r}
\mathrm{C}_{\text {(traphite) }}+\mathrm{O}_{2}(\mathrm{~g})=\mathrm{CO}_{2}(\mathrm{~g}) \\
\mathrm{C}_{\text {(grephite) }}+1 / 2 \mathrm{O}_{2}(\mathrm{~g})=\mathrm{CO}(\mathrm{g}) .
\end{array}
$$

Therefore, the recommended values of $\Delta G_{\mathrm{I}-\mathrm{IV}}^{\circ}$ are only the directly measured values, i.e. $\Delta G_{1}^{\circ}$ and $\Delta G_{\mathrm{II}}^{\circ}$ from this work and $\Delta G_{\mathrm{II}}^{\circ}$ and $\Delta G_{\mathrm{IV}}^{\circ}$ from calorimetric and spectroscopic measurements.

The standard Gibbs free energy change of carbonoxygen reactions (reaction R-I to R-IV) have been carefully computed and compiled by several authors. However, every author lists his own estimate of the accuracy in the computed free energy values. The estimated accuracy varies from $\pm 20 \mathrm{cal} / \mathrm{g}$-mole to $\pm 1 \mathrm{kcal} / \mathrm{g}$-mole. The thermochemical calculations and the extended discussion of their probable accuracy depend heavily on accuracy of the heat of combustion of graphite 
Table 1. Standard Gibbs free energy change of graphite-oxygen reactions

\begin{tabular}{|c|c|c|c|c|c|c|c|}
\hline & \multirow{3}{*}{ Reaction } & \multicolumn{3}{|c|}{ Present Work* } & \multicolumn{3}{|c|}{ Indirectly Calculated Values } \\
\hline & & \multicolumn{2}{|c|}{$\begin{array}{l}\Delta G^{\circ}(\mathrm{cal} / \mathrm{gm}-\mathrm{mole}) \\
=\mathrm{A}+\mathrm{B} \cdot \mathrm{T} \\
\end{array}$} & \multirow{2}{*}{$\begin{array}{l}\text { Uncertainty } \\
\text { in } \Delta \mathrm{G}^{\circ} \\
\text { (cal/gm-mole) }\end{array}$} & \multicolumn{2}{|c|}{$\begin{array}{l}\Delta G^{\circ}(\text { cal } / \text { gm-mole }) \\
\quad=A+B \cdot T\end{array}$} & \multirow{2}{*}{$\begin{array}{c}\text { Uncertainty } \\
\text { in } \Delta \mathrm{G}^{\circ} \\
\text { (cal/gm-mole) }\end{array}$} \\
\hline & & A & B & & A & B & \\
\hline$R-I$ & $\mathrm{CO}(\mathrm{g})+\mathrm{m}_{2} \mathrm{O}_{2}(\mathrm{~g})=\mathrm{CO}_{2}(\mathrm{~g})$ & $-67,250$ & 20.6 & \pm 100 & $-66,950$ & 20.2 & \pm 600 \\
\hline$R-I I$ & $\mathrm{C}(g r)+\mathrm{CO}_{2}(g)=2 \mathrm{CO}(g)$ & 42,050 & -42.8 & \pm 200 & 39,700 & -40.6 & \pm 1100 \\
\hline$R-I I I$ & $\mathrm{c}(g x)+\mathrm{O}_{2}(g)=\mathrm{CO}_{2}(g)$ & $-92,450$ & -1.6 & \pm 400 & $-94,200$ & -0.2 & \pm 100 \\
\hline R-IV & $\mathrm{C}(\mathrm{gr})+\mathrm{x}_{2} \mathrm{O}_{2}(g)=\mathrm{CO}(g)$ & $-25,200$ & -22.2 & \pm 300 & $-27,250$ & -20.4 & \pm 500 \\
\hline
\end{tabular}

*The standard Gibbs free energy change of reactions $R-I$ and $R-I I$ were directly obtained from experimental data. The results of reactions R-III and R-IV have been calculated

from reactions $R-I$ and $R-I I$.

(reaction R-III) as reported by Prosen et al.[5]. When an accuracy of $\pm 10.8 \mathrm{cal} / \mathrm{g}$-mole has been reported, one has to critically consider the effects of impurity content, impurity composition, pretreatment and the quality of the graphite. It has been shown [6] that the apparent heat of combustion measured by Prosen et al. [5] is $22.1 \mathrm{cal} / \mathrm{g}$ mole higher than the true value for a graphite assumed to contain equal $\mathrm{Si}$ and $\mathrm{Ca}$ impurities totaling $300 \mathrm{ppm}$ of ash. If the graphite sample was not prepared by heating to at least $2700^{\circ} \mathrm{C}$ in an inert atmosphere, the heat of combustion obtained was significantly higher $(40 \mathrm{cal} / \mathrm{g}$ mole). This result [6] which was fully corrected for ash characteristics, shows a significant effect on heat of combustion due to differences in degree of crystallinity.

In light of the above limitations of the indirectly computed values of free energy using heat of combustion data obtained by calorimetry, the present technique is direct, more accurate and also independent of the amount of ash and its chemical composition. Nevertheless, the degree of crystalline perfection of any carbon would have a profound effect on its thermodynamic properties.

Acknowledgements-This research was sponsored by the Advanced Research Projects Agency under contract number DAHC15-71-C-0283. The editorial help of Mrs. Diane Lyster during the preparation of this manuscript is gratefully acknowledged.

\section{REFERENCES}

1. S. K. Das, Ph.D. Thesis, The University of Michigan, Ann Arbor, Michigan (1974).

2. C. Wagner, Techniques of Metal Research, Vol. IV, Part 1, p. 1. Interscience, New York (1970).

3. J. W. Patterson, E. C. Bogren and R. A. Rapp, J. Electrochem. Soc. 114, 752 (1967).

4. K. Schwerdtfeger and E. T. Turkdogan, Techniques of Metal Research, Vol. IV, Part 1, p. 321. Interscience, New York (1970).

5. E. J. Prosen, R. S. Jessup and F. D. Rossini, J. Res. Nat. Bur. Std. 33, 447 (1944)

6. P. Hawtin, J. B. Lewis, N. Moul and R. H. Phillips, Phil. Trans. Roy. Soc., Ser. A 261, 67 (1966). 